\title{
Asymmetric Impact of Oil Price on Inflation: Evidence from Nepal
}

\author{
Dipesh Karki* \\ Hari Gopal Risal ${ }^{* *}$
}

\begin{abstract}
This paper investigates asymmetric oil price pass through on inflation in Nepal using time series data of 331 months from April 1987 to February 2018. The paper applies Nonlinear Autoregressive Distributed Lag (NARDL) model to estimate long run and short run asymmetric adjustment of refined petroleum products on Consumer Price Index (CPI). Finding shows presence of long run asymmetric adjustment between price of all petroleum products and CPI. However, when the model is controlled for monetary impact and price level of India, only the price of diesel is found to have long run asymmetric pass through into inflation. The long run cointegrating equation shows unit rise in price of diesel is accompanied by small contraction in CPI in long run by -0.048 units. Meanwhile unit fall in price of diesel is shown to have positive long run pass through in CPI by 0.431 units. This apparent anomaly could be attributed to fact that with rise in price of diesel, demand for cheaper adulterant like kerosene increases thus resulting in fall in CPI Similarly, fall in unit price of diesel could have overall increased industrial demand and other resources which in turn led to significant increase in CPI. Meanwhile, study didn't find any significant asymmetry in short run between CPI and petroleum products. However, in short run a significant impact on the CPI by actual size of increased price of Petrol and Diesel has been found. Hence, in short run, it shows that it is the size of price increase in Petrol and Diesel; not the price itself that has significant effect on the CPI. Since petroleum products in Nepal are not priced by market, these findings can provide guidelines for future oil pricing in reducing the spillover impact on general price level.
\end{abstract}

Key Words: oil prices, inflation, NARDL, asymmetric cointegrating relationship, symmetric oil price adjustment

\section{JEL Classification: E31, Q43, C12, C13, P44}

\footnotetext{
* Assistant Professor, Economics, Kathmandu University School of Management, Nepal. E-mail: dipesh@kusom.edu.np

** Assistant Professor, Finance, Kathmandu University School of Management, Nepal. E-mail: harigopal@kusom.edu.np
} 


\section{INTRODUCTION}

Inflation erodes purchasing capacity of people. Especially for fixed income households, inflation reduces the wealth and is often considered as negative tax. The main cause of inflation can be broadly distinguished into cost push and demand pull. However, it is pertinent that the underlying cause behind both is analyzed and its impact be assessed. In case of impoverished country like Nepal ills of inflation can be hardly understated. According to Shrestha and Chaudhary (2012), 10 percent rise in food price is likely to increase overall poverty by 4 percentages. This finding is very alarming as recent multidimensional poverty index report by national planning commission has found $28.6 \%$ of Nepal's population is multidimensionally poor (National Planning Commission, 2018). Besides poverty, high level inflation also is found to have negative impact in growth of economy. As per Bhusal and Silpakar (2011) the optimal threshold inflation for Nepal is 6 percent beyond which can jeopardize the economic growth. More recent study by NRB (2017) suggests that Nepal should target inflation around $6.4 \%$. Therefore it is very important that inflation be controlled in order to address poverty as well as economic growth.

In this situation it is important to analyze what factors actually leads to rise in inflation especially in Nepal. Most of the study shows that demand side factor and monetary factor plays a major role in Nepalese inflation. For instance, Mathema (1998) using granger bivariate causality has shown that carpenter's wage in Kathmandu and agricultural labors wage in terai was found to exert significant pressure on national price level. Meanwhile Bhattarai and Joshi (2009) have shown that stock return is used as long term hedge against the inflation. On the other hand, inflow of remittance is also found to increase the inflation in the country (Dahal, 2014). Besides these demand side factors, Paudyal (2014) found that in period of 1975 to 2014 budget deficit, Indian prices, broad money supply, exchange rate and real GDP were long run determinant of the inflation in Nepal. Further, Koirala (2008) has shown inflation expectation can contribute towards the inflation itself.

However, the analysis of inflation in Nepal through supply side factors seems lacking. According to Osmani and Bajracharya (2008), global oil crisis of 1970s did put inflationary pressure in Nepalese economy and Paudyal (2014) did attempted to isolate effect of oil price surge during 1979/80 oil price rise but was found to be insignificant. Meanwhile, International Monetary Fund (2011) has shown that international oil price and Indian inflation are impactful factors to Nepealese inflation. Despite these studies, actual role of supply factors within country influencing the inflation hasn't been investigated. Therefore it is necessary that a detailed study to analyze the effect of supply factors in Nepalese inflation be carried out. 
Nepal is landlocked country and its supply chain is heavily dependent on imported fuel. Nepal has signed a bilateral agreement with India in 1974 making Indian Oil Corporation sole supplier of fuel to Nepal prohibiting it to import oil from other countries; though revised version allows for buying crude oil from third country but it still needs to be refined in India (Bhattarai, 2017). This petro-politics thus further complicates oil price situation in Nepal. Besides, in Nepal the sole distribution of oil is done by Nepal Oil Corporation. (NOC) and hence price of oil is not determined by market forces. In addition to price control by NOC, apparent monopolist, also practice cross subsidy among the products. Furthermore, the presence of syndicates of dealers and retailers has added burden to general consumer (Sapkota, 2015). Therefore, it is important to assess the impact of oil price in inflation of the country. Further, study in industrial countries have shown that oil has asymmetric pass through into inflation (Chen, 2009) as it is generally perceived that the subsequent increase in inflation by increased fuel price remains sticky and does not diminish when oil price decreases. Thus, it is important to determine whether such phenomena also exist in Nepal considering its unique petro-economy. Since each petroleum product has different target market with petrol being consumed by high income bracket, kerosene by low income bracket and diesel by industries and transportation, it is interesting to analyze whether they have same level of impact. Based on this policy maker can decide which fuel pricing can help for sound economy. This paper, thus, attempts to analyze the impact of changes in oil price on consumer price of Nepal in both long and short term and further verify whether the impact is asymmetrical using Nonlinear ARDL model.

\section{REVIEW OF LITERATURE}

Macroeconomist in general holds consensus that global oil price shock in 1970s as a source for subsequent economic downturn as documented in seminal paper by Bruno and Sachs (1985). Despite this, there are debates on whether oil prices themselves are main cause of recession (Bohi, 1990; Bohi, 1991). Also two oil price shocks since 1990s didn't have substantial impact on the GDP growth and inflation (Blanchard \& Gali, 2007). However, it is widely accepted that oil price can at least in some degree impact the inflation. For instance, Hamilton (1996) opines that impact of oil price increase on subsequent inflation depends on past experience. Meanwhile Lee, Ni and Ratti (1995) opine that the effect of oil price increase is a function of their size relative to their current degree of variability. Further, Mork (1989) indicated asymmetric effect of oil price such that its rise matter more than its fall. This asymmetric pattern in oil price fluctuations is further corroborated by Lown \& Rich (1997). Chen (2009) using time varying pass through have found that appreciation of domestic currency, active monetary policy and openness in trade can explain decline in oil price impact on inflation. 
According to Hooker (2002) these varied description of oil price impact on macroeconomic variable such as inflation can be attributed to the fact that oil price are a time series data without an underlying theoretical framework to explain its interplay which is further complicated by monetary policy. However, Bernanke et al. (1997) and Hamilton and Herrera (2004) have questioned the efficacy of monetary policy in eliminating recessionary consequences of oil shock inflation rates. Further, several studies have shown unstable relationship of oil prices especially in recent data. Lee et al. (1995) and Hamilton (1996) have suggested usages of complicated nonlinear and asymmetric filters to avoid the misspecification in relationship. This structural issue is not only in the case of data from US alone but among several countries as well. For example, DeGregorio et al. (2007) applying rolling VAR and Phillip Curve model in data of 34 developed and developing countries found declining oil pass through. This declining impact is also witnessed in a study by Chen (2009). Using data of 19 industrial countries, Chen (2009) found degree of oil price pass through varies across countries and is positively correlated with the energy imports.

Literature appears to segregate the impact of oil price pass through in varying degree among oil importing nation and exporting one. For instance, in a study of nine oil importing Southern and Southeastern countries by Jongwanich and Donghyun (2011) concludes that the magnitude of oil price pass-through is limited. The major reason behind such can be attributed to the price control and subsidy that has been provided to mitigate the impact of oil price rise. For example, Tang, Wu and Zhang (2010) shows that in China despite oil price surge reducing interest rate, overall output and rising inflation, the long term impact is curbed by price control. Meanwhile, reverse was seen in Kenya, where a 10 percent rise in oil price was followed by meager 0.5 percent increase in inflation while in long run impact reached up to 1 percent (Kiptui, 2009). Similarly, Akcelik and Ognuc (2016) applying vector autoregressive model showed that 10 percent change in international crude oil contributed to 0.42 percent change in consumer inflation in Turkey, which is a major oil importing nation. Despite the several study across oil importing nation a strict consensus on oil price pass through hasn't been established.

Similarly, among the oil exporting nations too the diversity on impact of oil price pass through can be seen. Castro et al. (2017) in a study of four major European economies Germany, France, Spain and Italy found diverse pattern across disaggregate economy. Karimili et al. (2016) has found oil price shock significantly affecting domestic inflation in Russia, Azerbaijan and Kazakasthan. A study conducted in Indonesia by Adam et al. (2015) using difference equation model shows that unit increase (decrease) in world crude oil prices caused the inflation rate to go up (fall) by 0.33 percent. The impact is varied as $\mathrm{Ju}$ et al. (2014) has reported positive effect of oil price on inflation in China whereas 


\begin{abstract}
Ahmed and Wadud (2011) found a negative association in Malaysia and Iwayemi and Fowowe (2011) and Roeger (2005) shows no association between oil prices and inflation in Nigeria and EU respectively. Meanwhile Adeniyi et al. (2011) applying ARDL in Phillp curve found high price sensitivity to oil price volatility in Nigeria. Sek et al. (2015) has suggested these varied findings perhaps could be explained by differences in the economic conditions of the countries under investigation. These well documented studies have been limited and all of them have so far focused only in developed and developing economy hence similar studies in context of least developed country like Nepal is hitherto lacking.
\end{abstract}

Nepal especially poses a unique case as it doesn't have crude oil sources to meet rapidly growing demand for petroleum products. According to a study, petroleum products constitute about 15 percent of total energy consumption in Nepal. Further, Nepal has no oil refinery and hence has to depend entirely on oil imports from India for meeting its energy needs. Similarly, Nepal Oil Corporation (NOC) is a sole monopolist to import and distribute petroleum products in Nepal. In 2002, a provision of petroleum import arrangement agreement was signed between NOC and IOC, which required Nepal to import crude oil from international market and hand over to IOC which in turn would supply equivalent volume of refined petroleum products to Nepal. As a part of agreement, Haldiya Refinery Transfer Price was to be used as export price to NOC. Meanwhile, since February 2006, government adopted a wholesale pricing system that requires announcing wholesale prices. With this structural rigidity the oil pricing doesn't follow free market dynamics. Hence, Nepal's case poses a unique picture in the context of oil pricing and its eventual impact on the national economy. A comparative study of inflation in Nepal and India conducted by Nepal Rastra Bank suggests that price of petroleum products pushes the cost of freight, carriage and cost of other goods service eventually causing inflation (NRB, 2011). It further points out that trying to contain inflation at certain level despite food surplus has witnessed challenge from supply side management due to rising fuel price. Further, International Monetary Fund (2011) states that using both stylized analysis and econometric analysis; applying VAR indicates India's inflation and international oil price as main driving force behind Nepalese inflation. This means increase in fuel prices increases cost of production and transportation that ultimately raise the general price level of goods and services. Besides, it suggests that the food price inflation might be because of correlation between oil price and fertilizers required for crop production. 


\section{METHODOLOGY}

\section{Data and Variables}

The monthly oil price data from April 1987 to February 2018 has been downloaded from official website of Nepal Oil Corporation. The data contains price list of petrol, diesel, and kerosene and LPG gas individually. Further, price of LPG cooking gas is available only from April 1996. Figure 1, Figure 2 and Figure 3 show the date and price changes of petrol, diesel and kerosene respectively.

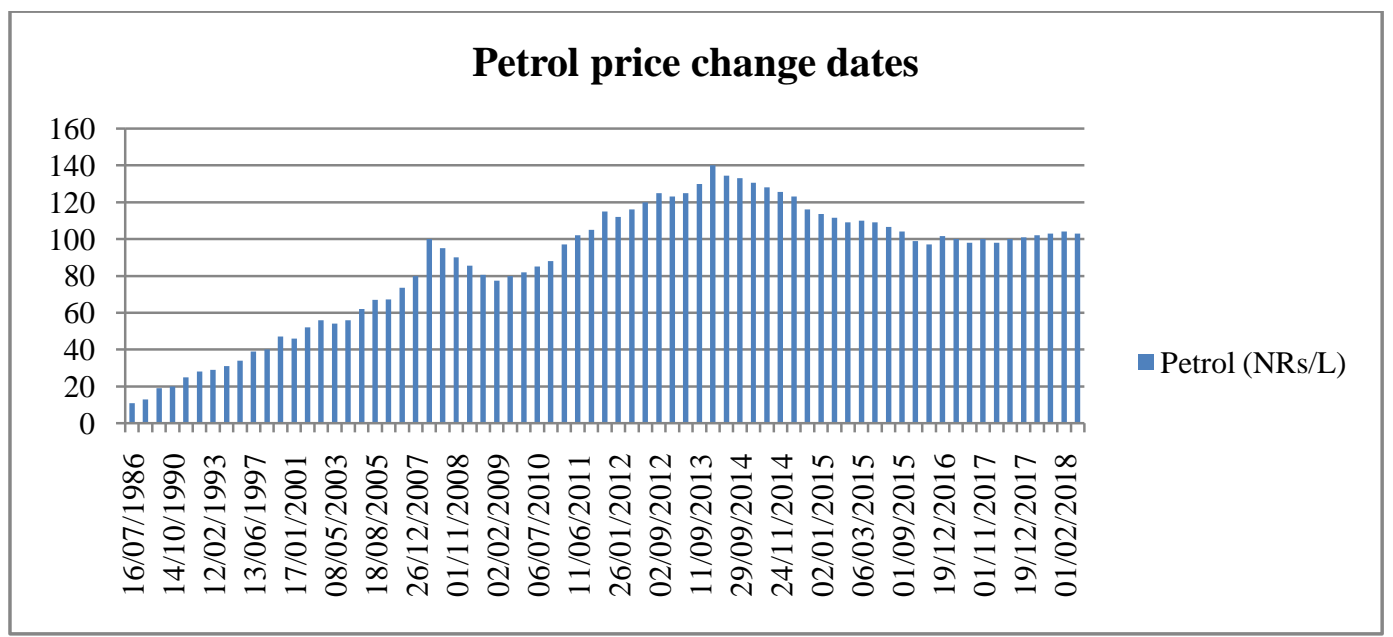

Figure 1: Petrol price and change date

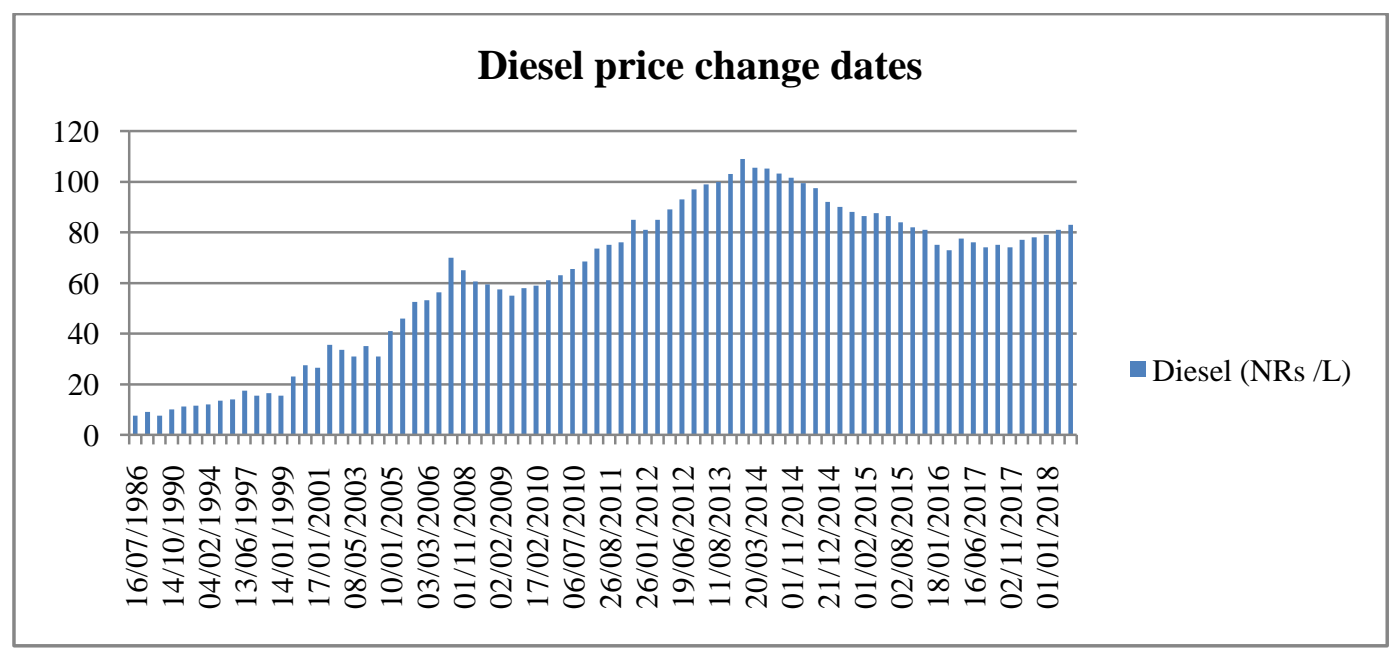

Figure 2: Diesel price and change date 


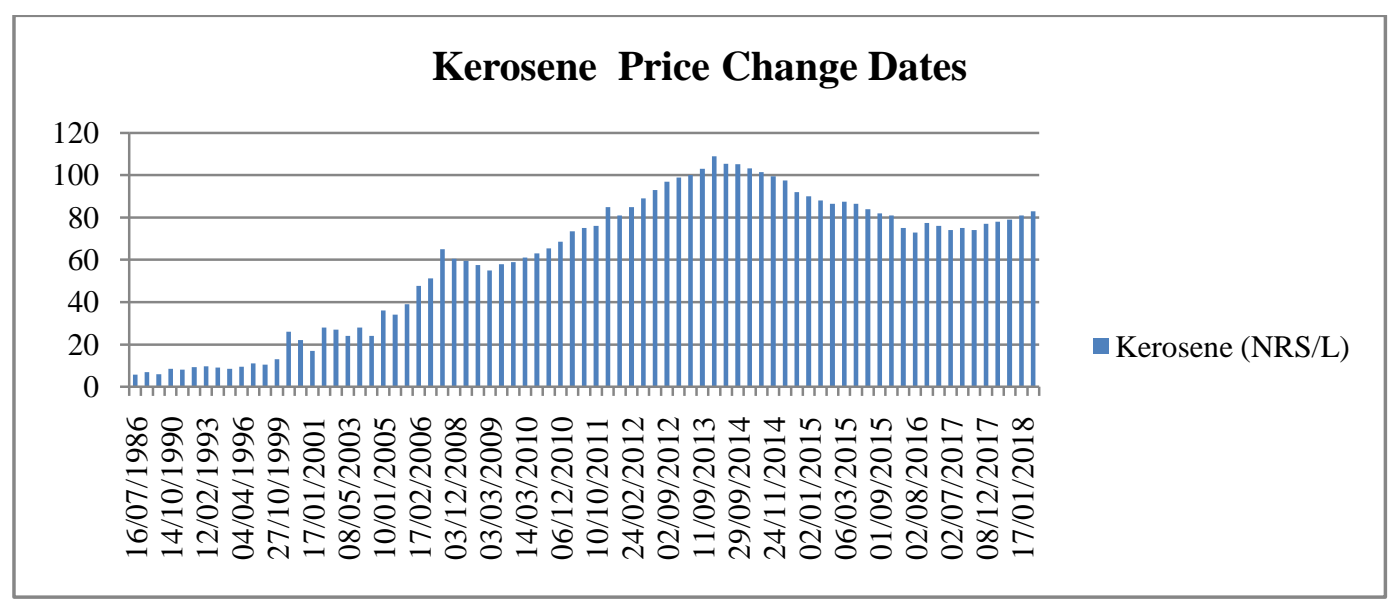

Figure 3: Kerosene Price and Change Date

Table 1 provides the brief description about how the price has varied among petrol, diesel and kerosene since 1987 to 2018. It shows that price of diesel has changed more than other products. Since the start Petrol is priced higher than diesel and kerosene. Also form November 1, 2008 the price of diesel and kerosene has been equalized.

Table 1: Description of Price Change

\begin{tabular}{lccccc}
\hline & \multirow{2}{*}{$\begin{array}{c}\text { No. of times } \\
\text { change }\end{array}$} & \multicolumn{2}{c}{ Minimum } & \multicolumn{2}{c}{ Maximum } \\
\cline { 3 - 6 } & & Price & Price set Date & Price & Price set Date \\
\hline Petrol & 70 & 12.9 & $4 / 1 / 1987$ & 140 & $3 / 14 / 2014$ \\
Diesel & 78 & 7.5 & $7 / 16 / 1986$ & 109 & $3 / 14 / 2014$ \\
Kerosene & 77 & 5.5 & $7 / 16 / 1986$ & 109 & $3 / 14 / 2014$ \\
\hline
\end{tabular}

Meanwhile, corresponding monthly CPI index of Nepal with October 2014 as base month is obtained from official website of Nepal Rastra Bank. The month to month growth of CPI is shown in Figure 4. It shows that there was a high volatility during 1987 to 2010 and the fluctuations abated in recent times. The average month to month growth during 371 month period is found to be positive 0.59 percent while standard deviation is found to be 0.03 . 


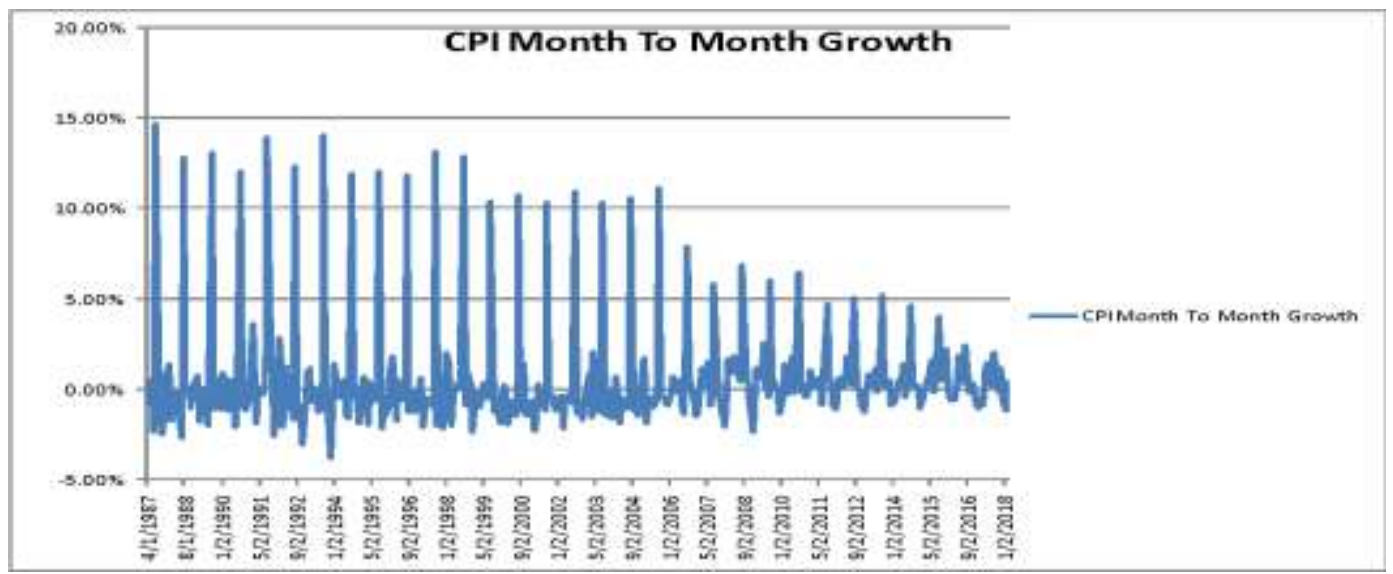

Figure 4: Month to Month CPI growth in percent

Figure 5, on the other hand, shows the movement of price of Petrol, Diesel, Kerosene and LPG gas in the given time period.

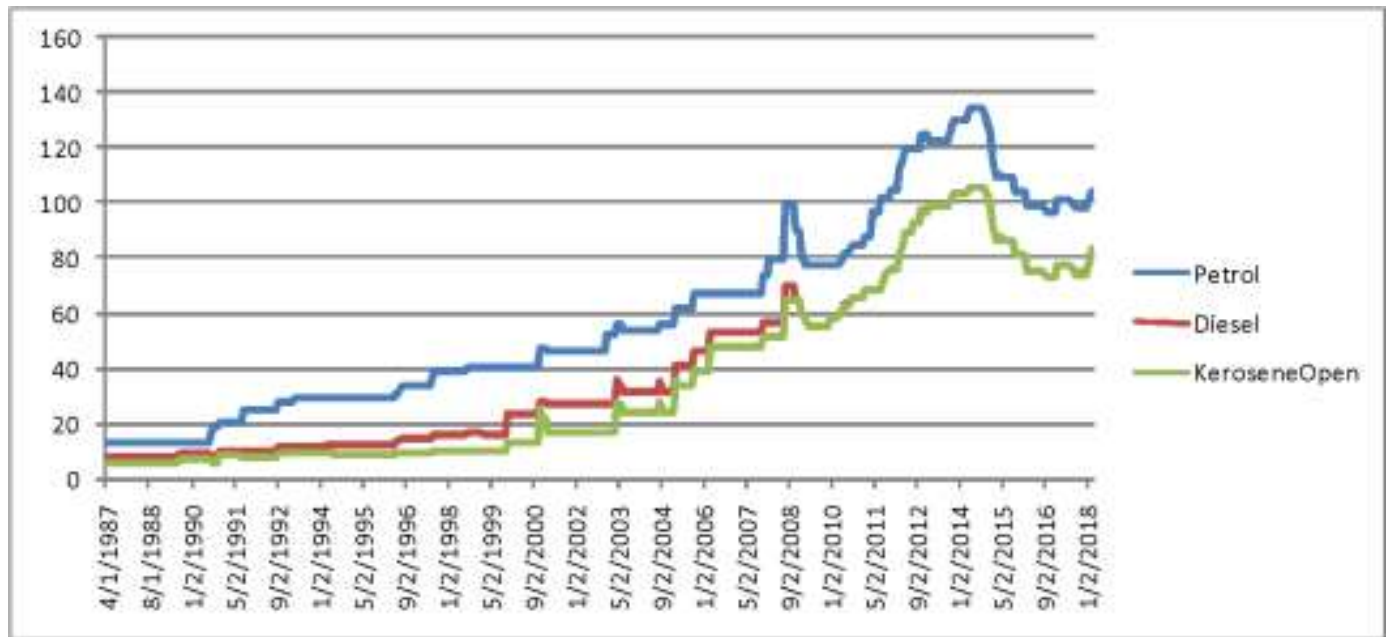

Figure 5: Movement of Price of Petrol, Diesel and Kerosene

The plot indicates high correlation between three which is substantiated by following Karl Pearson correlation table2.

Table 2: Correlation between Petrol, Diesel and Kerosene

\begin{tabular}{llll}
\hline & Petrol & Diesel & Kerosene \\
\hline Petrol & 1 & & \\
Diesel & 0.9887 & 1 & \\
Kerosene & 0.9812 & 0.9961 & 1 \\
\hline
\end{tabular}


Since it is difficult to actually pinpoint which oil product among three refined petroleum products, viz- petrol, diesel and kerosene, mainly contribute to inflation. The study uses all three of them separately. The intuition behind the usage is that all three products cater to different market segment. For instance, petrol is generally consumed for cars and private vehicles and hence it is demanded by high income market segment. Meanwhile, diesel is used by heavy vehicles like bus and trucks and hence mainly used for transportation affecting supply chain. Besides, it is also highly demanded by industries as fuel. On the other hand, kerosene is used by low income household for mainly cooking purpose. The price of all three products along with the CPI is plotted in Figure 3 below.

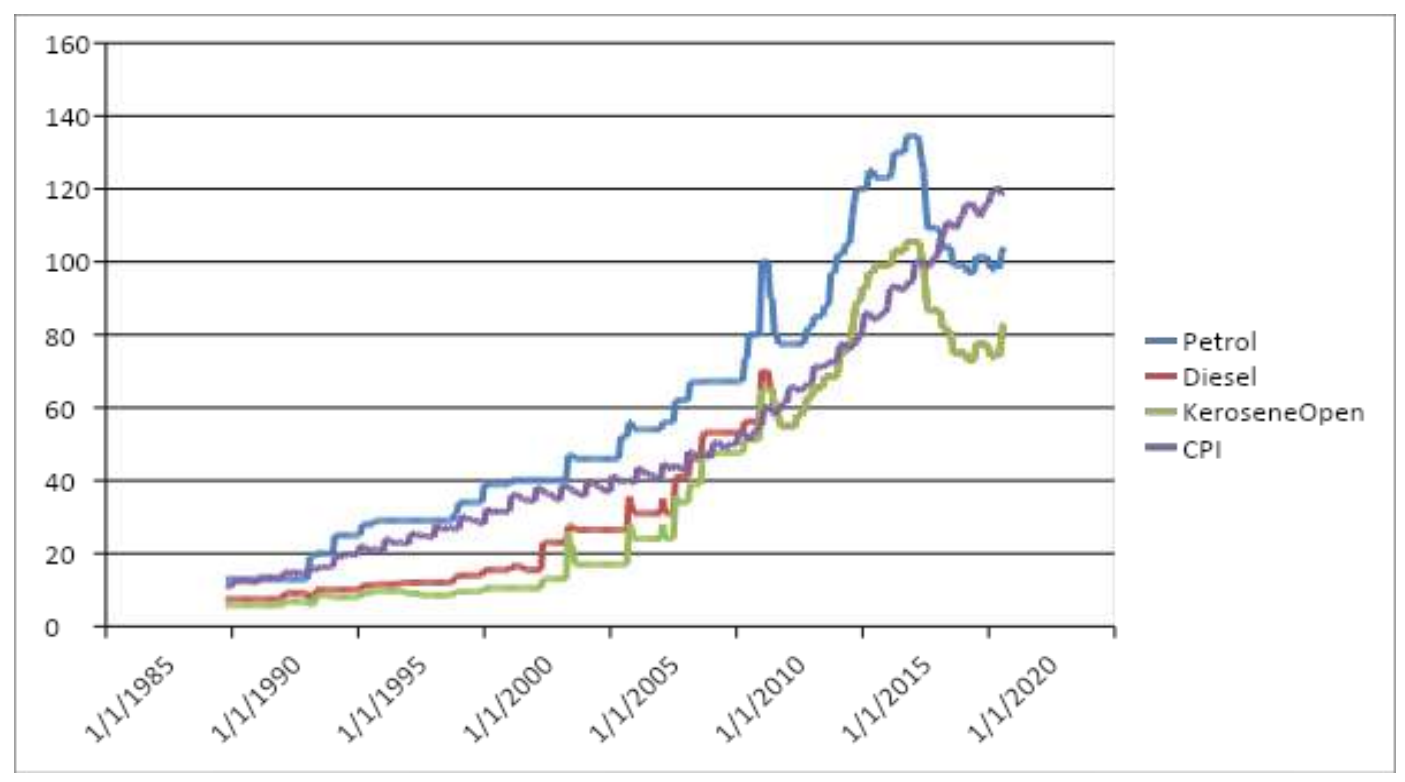

\section{Figure 6: Oil Price and CPI Movement}

The image shows that there had been relatively slow growth in all four variables gentle rise from 1987 to late 90s followed by accelerated growth after turn of millennium. Scatter plot between CPI and all three petroleum product is shown in figure 7 . 


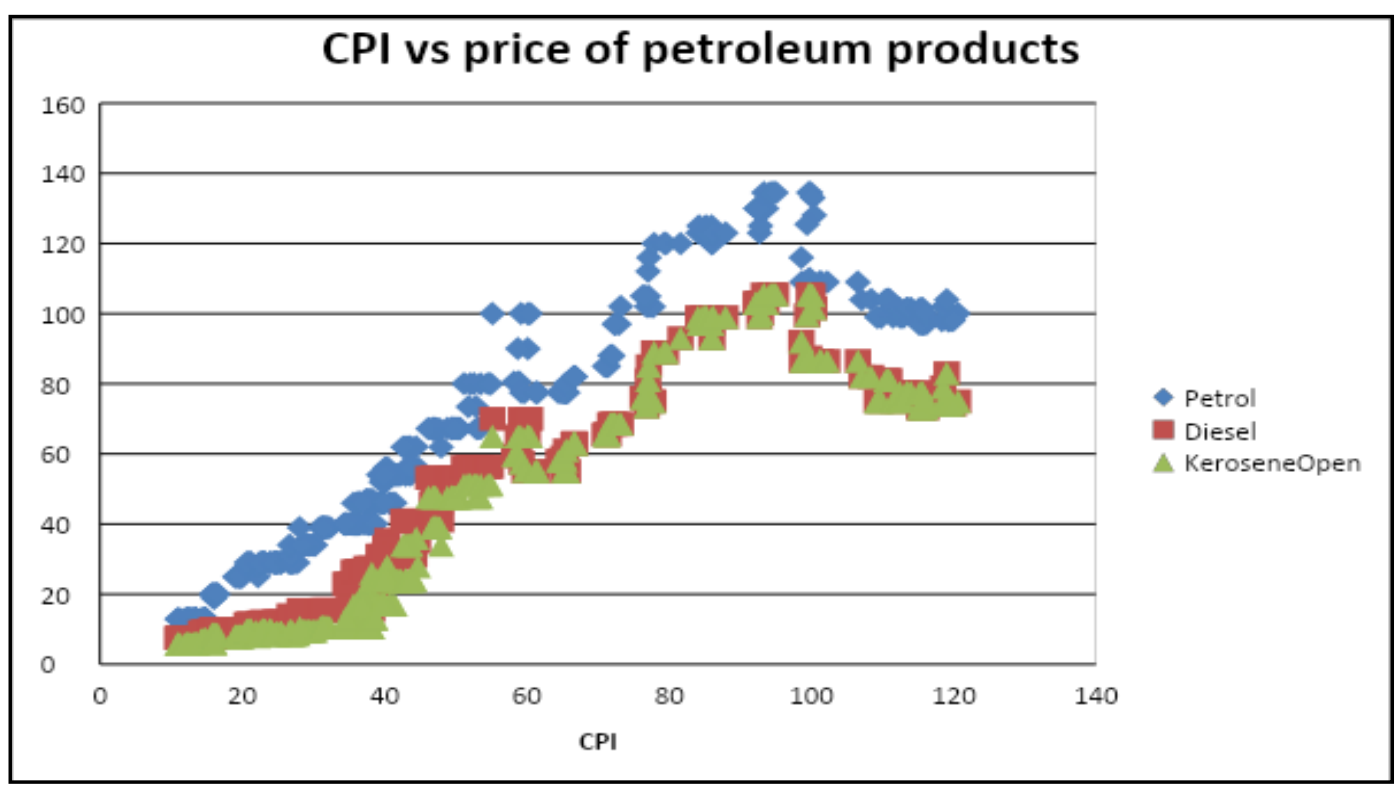

Figure 7: Scatter Plot between CPI and Petroleum Products

In addition to CPI and Petroleum Products this study uses money supply of Nepal (M2) and Wholesale Price Index (WPI) of India as the control variables. The reason for controlling money supply is because literature shows that money supply has strong effect in the general price level (Hamburger \& Zwick, 1981). According to Milton Friedman, inflation is always and everywhere monetary phenomenon (Barro, 2007). This provides the growth of money supply as well as financial deepening (Levine \& Zervos, 1998). The yearly data was obtained from World Development Indicators. In order to convert it to monthly, standard cubic spline interpolation was applied (Suits, Mason, \&Chan, 1978). Similarly, wholesale price index of India has been chosen as an another control variable as India and Nepal share open border and Nepal has more than two-third trade size with India alone. So, any price movement in India can have spillover effects on Nepal. The WPI was obtained from the website of Reserve Bank of India (RBI)

\section{Econometric Tools}

The paper primarily uses cointegration analysis to determine the long run and as well as the short-run interactions between oil price and CPI. The entire method has been outlined in the following steps:

\section{Unit Root Test}

Cointegration analysis helps to solve the spurious regression problem that appears in time-series data due to presence of non-stationarity (Hendry \& Juselius, 2000). Therefore, it is imperative that unit root check is to be applied in both time series 
to determine integrated order of both time series. But, before applying the unit root test it is important to determine the appropriate lag to take for both time series. The most common approach for model order is to minimize one or more information criteria that include Akaike Information Criterion (AIC), Schwarz-Bayes Criterion (SBIC), Akaike's Final Prediction Error Criterion (FPE), and Hannan-Quinn Criterion (HQIC). The comparative analysis of all these information criteria is given in Lütkepohl (2005).

\section{Granger Causality}

To check the direction of relationship between CPI and fuel price the paper checks for Granger Causality (Granger, 1969). If any time series signal X granger causes another signal $\mathrm{Y}$ then it implies past values of $X$ should contain enough information that can predict $Y$ beyond the information contained in past values of Y.

\section{Johansen Test of Cointegration}

Johansen (1988) test is applied to determine the number of possible co-integrating equation between two variables. Johansen test actually produce two statistics: maximal eigenvalue of the stochastic matrix and the trace of the stochastic matrix. The maximum eigenvalue test conducts separate tests on the individual eigenvalues and the null hypothesis is number of cointegrating vectors is equal to ' $r$ ' where as the trace test is a joint test where the null hypothesis is that the number of cointegrating vectors is less than or equal to ' $r$ '. Here ' $r$ ' is some arbitrary value (Ghimire et al., 2015).

\section{NonLinear Autoregressive Distributed Lag Model (NARDL)}

After establishing the number of possible co-integrating equations usually, Error Correction Model such as Vector Error Correction Model is employed to determine the long run relationship (Anderson et al., 2002). However, the VECM model assumes symmetry in the relationship among both dependent and explanatory variables that is the response of dependent variable will be same for both rise and fall of explanatory variables. Since the study deals on asymmetry of oil prices impact on inflation it applies Nonlinear Autoregressive Distributed Lag Model (NARDL) for analysis (Atil, Lahiani, \& Nguyen, 2014). The model developed by Shin et al. (2014), Shin (1998) and Pesaran et al. (2001), has been used determining the asymmetric long and short run dynamics between oil price and CPI. In this study, the long run relation between CPI and petroleum products along with control variables is given by following equation.

$$
C P I=\beta_{0}+\beta_{p} X+Z \beta+\epsilon
$$


Where,

$\mathrm{X}=\left[\right.$ Petrol $^{+}$, Petrol $^{-}$, Diesel $^{+}$, Diesel $^{-}$, Kerosene $^{+}$, Kerosene $\left.^{-}\right]$

$\mathrm{Z}=[\mathrm{M} 2$ to GDP, WPI_India $]$

$\beta_{p}=\left[\beta_{\text {petrol }+}, \beta_{\text {petrol }-,}, \beta_{\text {diesel }+}, \beta_{\text {diesel }-}, \beta_{\text {kerosene }}+, \beta_{\text {kerosene }-}\right]$ are the cointegrating vectors of long run

$\beta=\left[\beta_{M 2 \text { toGDP }}, \beta_{\text {WPI india }}\right]$

and finally if $\mathrm{K} \in\{$ Petrol,Diesel,Kerosene $\}$ then $K^{+}$and $K^{-}$are the partial sums of positive and negative change in any arbitrary independent variable given by

$$
\begin{aligned}
& K_{t}^{+}=\sum_{i=1}^{t} \Delta K_{t}^{+}=\sum_{i=1}^{t} \max \left(\Delta K_{t}, 0\right) \\
& K_{t}^{-}=\sum_{i=1}^{t} \Delta K_{t}^{-}=\sum_{i=1}^{t} \min \left(\Delta K_{t}, 0\right)
\end{aligned}
$$

If the cointegrating coefficients $\beta_{k+} \neq \beta_{k-}$ then it can be shown that the asymmetric adjustment of Kth variable on CPI does exist in long run

The ARDL equivalent formulation of short run relationship as explained in Shin et al. (2014), can be framed as following

$$
\Delta C P I_{t}=\alpha+\gamma_{p} X_{t-1}+\mathrm{Z}_{\mathrm{t}-1} \gamma+\sum_{i=1}^{p} \emptyset_{i} \Delta C P I_{t-1}+\sum_{j=1}^{q} \varphi_{j} \Delta X_{t-j}+\epsilon
$$

Where,

$\gamma_{p}=\left[\gamma_{\text {petrol }+}, \gamma_{\text {petrol }-,} \gamma_{\text {diesel }+}, \gamma_{\text {diesel }-}, \gamma_{\text {kerosene }+}, \gamma_{\text {kersoene }-}\right]$ are short run adjustment coefficients of independent variable on change in CPI;

$\gamma=\left[\gamma_{M 2 t o G D P}, \gamma_{\text {WPI india }}\right]$ are short run adjustment coefficients of control variable on change in $\mathrm{CPI}$

$\mathrm{p}$ and $\mathrm{q}$ are the lag orders;

$\sum_{i=1}^{p} \emptyset_{i}$ is short run impact of previous CPI change lag;

$\sum_{i=1}^{q} \varphi_{j}$ are the short run impact of increase and decrease in independent variable on CPI respectively and significance of all the coefficients are determined using the Wald F test .

It should be however noted that the NARDL can be applied on time series containing both $\mathrm{I}(0)$ and $\mathrm{I}(1)$ series. But the entire assumption will become invalid if any of variable is of $\mathrm{I}(2)$. This is the reason why unit root test is important. 


\section{EMPIRICAL RESULTS AND DISCUSSION}

As both variables oil price index and CPI shows a trend it is always intuitive to check for the presence of unit root. However, before applying the unit root test it is important to see what is the appropriate lag to take for both time series.

\section{Table 3: Lag Selection Criteria for CPI}

\begin{tabular}{lllll}
\hline Lag & FPE & AIC & HQIC & SBIC \\
\hline 0 & 931.203 & 9.67435 & 9.67858 & 9.685 \\
1 & $1.37968^{*}$ & $3.15973^{*}$ & $3.16819^{*}$ & $3.18101^{*}$ \\
2 & 1.38703 & 3.16504 & 3.17773 & 3.19697 \\
3 & 1.38633 & 3.16504 & 3.18145 & 3.2071 \\
4 & 1.39259 & 3.16904 & 3.19018 & 3.22225 \\
\hline
\end{tabular}

As shown in table 3, for CPI the significant lag based on four metrics final prediction error (FPE), Akaike's information criterion (AIC) and the Hannan Quinn Information Criterion (HQIC) and SBIC is lag 1 meanwhile as shown in Table 4 for Oil price the best lag according to FPE, AIC and HQIC is VAR lag 3.

\section{Table 4: Significant Lag Selection Criteria for Oil Products}

\begin{tabular}{lllllll}
\hline Criteria & \multicolumn{2}{c}{ Petrol } & \multicolumn{2}{c}{ Diesel } & \multicolumn{2}{c}{ Kerosene } \\
\cline { 2 - 7 } & Lag & Value & Lag & Value & Lag & Value \\
\hline FPE & 3 & 4.1176 & 2 & 2.86795 & 1 & 3.51382 \\
AIC & 3 & 4.25315 & 2 & 3.89147 & 1 & 4.09458 \\
HQIC & 3 & 4.27006 & 1 & 3.90364 & 1 & 4.10304 \\
SBIC & 1 & 4.2995 & 1 & 3.91647 & 1 & 4.11586 \\
\hline
\end{tabular}

As the table shows, for petrol the 3 lag selection is most appropriate while for diesel the optimum lag selection appears to be either 2 or 1 . Meanwhile for kerosene the appropriate lag appears to be 1 . In such circumstances since there is no majority we follow democratic process and make model parsimonious by using the average lag order of 2 (Nielsen, 2006).

Following the lag selection for determining unit root Augmented Dickey-Fuller test (Dickey and Fuller, 1976) is applied to test for the presence of unit root. The result of which is tabulated in Table 5: 
Table 5: ADF test for CPI, CPI (-1), Oil Index, Oil Index (-1)

\begin{tabular}{llll}
\hline Series & Test Statistics & p-value & Decision \\
\hline$Z(t)$ of CPI & 2.211 & 0.9989 & Unit Root Exist \\
$Z(t)$ of CPI $(-1)$ & $\mathbf{- 1 9 . 0 4 9}$ & $\mathbf{0 . 0 0 0 0}$ & Unit Root is Absent \\
$Z(t)$ of Petrol & -0.582 & 0.8749 & Unit Root Exist \\
$Z(t)$ of Petrol $(-1)$ & $\mathbf{- 1 7 . 3 9 5}$ & $\mathbf{0 . 0 0 0 0}$ & Unit Root is Absent \\
$Z(t)$ of Diesel & -0.107 & 0.9487 & Unit Root Exist \\
$Z(t)$ of Diesel $(-1)$ & $\mathbf{- 1 7 . 2 7 9}$ & $\mathbf{0 . 0 0 0 0}$ & Unit Root is Absent \\
$Z(t)$ of Kerosene & -0.018 & 0.9570 & Unit Root Exist \\
$Z(t)$ of Kerosene $(-1)$ & $\mathbf{- 1 8 . 7 0 7}$ & $\mathbf{0 . 0 0 0 0}$ & Unit Root is Absent \\
\hline
\end{tabular}

Since calculated Z score of CPI is 2.211 whose magnitude is less than the tabulated value hence we cannot reject null hypothesis of presence of unit root. Meanwhile for first difference of CPI the tabulated values comes to -19.382 which is greater in magnitude we cannot accept null hypothesis. Hence, the CPI can be considered to be integrated process of order one I (1). Similarly, the tables shows all oil products (petrol, diesel and kerosene) are also process of order one I(1). Since all variables are non-stationary time series data we cannot apply direct OLS estimation as it always gives spurious relationship.

In addition to the unit root, the granger causality test has been performed to see if we can establish a direction of causality between CPI and dependent variable. Since all the variables are integrated in the order I(1), Stock and Watson (1988) and Park and Phillipes (1988) have suggested that the conventional granger causality of vector auto regression (VAR) cannot be applied as Wald test statistics doesn't follow asymptotic chi-square distribution due to presence of nuisance parameter in order I(1). Thus, the paper utilizes the method suggested by Toda and Yamamoto (1995) that allows computing Granger causality on nonstationary process by augmenting the unrestricted VAR model by $(\mathrm{k}+\mathrm{d})$ th order where $\mathrm{k}$ is optimal number of lag length and $\mathrm{d}$ is the integrated order. Table 6 shows the result of test according to which all three petroleum products granger causes CPI but no other way around.

Table 6 : Granger Causality Test/Block exogenity wald test

\begin{tabular}{lccl}
\hline Null Hypothesis & Chi-square & p-value & Decision \\
\hline Petrol does not Granger Cause CPI & & 0.0104 & Reject Null \\
CPI does not Granger cause Petrol & 0.513377 & 0.9722 & Do not reject Null \\
Diesel does not Granger Cause CPI & 7.381062 & $\mathbf{0 . 0 6 0 7}$ & Reject Null at 90 percent \\
CPI does not Granger cause Diesel & 0.360891 & 0.9482 & Do not reject Null \\
Kerosene does not Granger Cause CPI & 7.284720 & $\mathbf{0 . 0 6 3 4}$ & Reject Null at 90 percent \\
CPI does not Granger cause Kerosene & 0.131994 & 0.9877 & Do not reject Null \\
\hline
\end{tabular}


To see if there is a long run stable relationship Johansen Test is applied. The summary of various functional form of possible co-integrating equation based on critical value given by Mackinnon-Haug-Michelis (1999) is shown in Table 7 which suggest that under assumption data has no trend based on both Trace Statistics and Maximum Eigenvalue test at least one co-integrating equation exist for functional form of no intercept and no trend as well as for with intercept and no trend. Meanwhile under assumption of data having trends the result was insignificant. Thus, the Johansen test indicates presence of at least one cointegrating equation without any specific trend.

Table 7 : Summary of Possible of Co-Integrating Equation Based on Johansen Test

\begin{tabular}{|c|c|c|c|c|c|c|c|c|c|c|c|}
\hline \multirow[b]{2}{*}{ Data Trend } & \multicolumn{2}{|l|}{ CE Form } & \multirow[b]{2}{*}{$\begin{array}{l}\text { No Of } \\
\text { CE* }\end{array}$} & \multirow[b]{2}{*}{$\begin{array}{l}\text { Eigen } \\
\text { Value }\end{array}$} & \multirow[b]{2}{*}{$\begin{array}{l}\text { Trace } \\
\text { Stat }\end{array}$} & \multirow{2}{*}{$\begin{array}{l}\text { Max- } \\
\text { Eigen } \\
\text { Stat }\end{array}$} & \multicolumn{2}{|l|}{ Rank Test } & \multicolumn{2}{|c|}{ Max-Eig Test } & \multirow{2}{*}{$\begin{array}{l}\text { Decision } \\
\text { No. } \\
\text { of CE }\end{array}$} \\
\hline & Intercept & Trend & & & & & $\begin{array}{l}\text { Critical } \\
\text { Value } \\
\end{array}$ & $\begin{array}{l}\mathrm{p}- \\
\text { value }\end{array}$ & $\begin{array}{l}\text { Critical } \\
\text { Value } \\
\end{array}$ & $\begin{array}{l}\mathrm{p}- \\
\text { value }\end{array}$ & \\
\hline & & & 0 & 0.116869 & 56.80627 & 45.48691 & 40.17493 & 0.0005 & 24.15921 & 0.0000 & \\
\hline \multirow[t]{2}{*}{ None } & No & No & 1 & 0.022188 & 11.31936 & 8.212075 & 24.27596 & 0.7598 & 17.79730 & 0.6827 & 1 \\
\hline & & & 0 & 0.117055 & 63.44054 & 45.56419 & 54.07904 & 0.0059 & 28.58808 & 0.0002 & \\
\hline \multirow[t]{2}{*}{ None } & Yes & No & 1 & 0.024834 & 17.87634 & 9.204123 & 35.19275 & 0.6405 & 9.1645 & 0.6405 & 1 \\
\hline & & & 0 & 0.055205 & 34.86493 & 20.78426 & 47.856 & 0.4511 & 27.58434 & 0.2895 & \\
\hline \multirow[t]{2}{*}{ Linear } & Yes & No & 1 & 0.024158 & 14.08066 & 8.950405 & 29.79707 & 0.8361 & 29.13162 & 0.8364 & 0 \\
\hline & & & 0 & 0.0411 & 21.1074 & 16.1338 & 25.8721 & 0.1750 & 19.3870 & 0.1396 & \\
\hline \multirow[t]{2}{*}{ Linear } & Yes & Yes & 1 & 0.0135 & 4.9736 & 4.9736 & 12.5180 & 0.6002 & 12.5180 & 0.6002 & 0 \\
\hline & & & 0 & 0.0231 & 9.5283 & 8.5250 & 18.3977 & 0.5267 & 17.1477 & 0.5447 & \\
\hline Quadratic & Yes & Yes & 1 & 0.0027 & 0.9933 & 0.9933 & 3.8415 & 0.3189 & 3.8415 & 0.3189 & 0 \\
\hline
\end{tabular}

* CE: Cointegrating Equation

Once the number of cointegrating vector established the paper applies standard nonlinear autoregressive distributed lag (NARDL) model to analyze the impact of oil price on CPI. The intuition is to see the impact with and without controlling the possible endogenous variables.

\section{a. Without Control Variables}

Table 8 shows the long run relationship of CPI with Petrol, Diesel and Kerosene without other control variables. 
Table 8: NARDL Asymmetry Statistics without Control Variable

\begin{tabular}{|c|c|c|c|c|c|}
\hline \multicolumn{2}{|l|}{ Variables(K) } & \multicolumn{2}{|c|}{ Long Run Effect of K on CPI } & \multicolumn{2}{|r|}{ Asymmetry (F-stat) } \\
\hline \multirow{3}{*}{ Petrol } & & Effect $(+)$ & Effect(-) & Long Run & Short Run \\
\hline & Coeff & 0.515 & 0.162 & \multirow{2}{*}{$7.571 * * *$} & \multirow{2}{*}{0.2502} \\
\hline & F-stat & $28.38 * * *$ & 0.4179 & & \\
\hline \multirow[t]{2}{*}{ Diesel } & Coeff & 1.288 & -0.581 & & \\
\hline & F-stat & $14.02 * * *$ & 1.38 & $1.575 * * *$ & 0.0857 \\
\hline Kerosene & Coeff & -1.305 & 0.912 & & \\
\hline \multirow{2}{*}{\multicolumn{2}{|c|}{$\begin{array}{l}\text { Bound Test of } \\
\text { F-stat } \\
\text { nonlinearity }\end{array}$}} & $23.91 * * *$ & $14.48 * * *$ & 1.589 & 0.4477 \\
\hline & & \multicolumn{4}{|c|}{$\begin{array}{l}0.047911 * * * \\
\mathrm{t} \_ \text {BDM }=-5.2720 \mathrm{~F} \_\mathrm{PSS}=5.6554 * * * \\
\text { [above } 99 \% \text { LB }=3.88 \text { and } 99 \% \text { UB }=5.30 \text { as per PESARAN }(2001)]\end{array}$} \\
\hline
\end{tabular}

The analysis shows that long run asymmetry exist among Petrol and Diesel in impacting inflation. Further, the rise in price of petrol appears to have significant positive impact on CPI with 1 unit rise accompanied by 0.515 units. Meanwhile unit fall in petrol price shows 0.162 unit rise on CPI suggesting upward stickiness of inflation to petrol price. However, the result is insignificant hence this assertion cannot be validated. Similarly, impact of diesel appears to have more elastic effect with one unit increase in it followed by 1.2 unit rise in CPI. This well explains how increase in diesel price affects the heavy vehicles like buses ferrying passengers and trucks transporting goods. This obviously creates supply shock and has pronounced effect on inflation. Meanwhile fall in Diesel price shows unit fall is followed by 0.581 unit decline in CPI however this result is also statistically insignificant hence we are unable to reject the hypothesis that fall in diesel price has no effect on CPI. In case of kerosene though long run asymmetry appeared to be lacking, the impact however shows that Kerosene price has negative effect on CPI with unit rise in Kerosene price is accompanied by a decline in CPI by -1.3 unit. This can be explained as Kerosene is demanded by the low income household and they may resort to other fuels like firewood for energy purpose. This can be corroborated through Rao (2013) in a study in Kerosene subsidy in Maharastra India has shown that the kerosene is used by poor household who do not have access to biomass. Further, a recent survey in Nigeria and Bangladesh have shown that with rise in oil price poor household's bio mass consumption increases (Durotoluwa, 2019). On the other hand, fall in kerosene price appears to have significant positive impact on CPI suggesting that Kerosene might be used as adulterant in Diesel a very well-known practice (Yadav et al., 2005). In fact when 
kerosene and diesel price was equalized in Nepal, there was immediate 40 percent increase in sale of diesel accompanied 60 percent decline in sale of kerosene. This suggests that diesel was earlier adulterated with kerosene when latters price was low (Kojima, 2009). The impact of adulteration is reduced life of vehicle and higher maintenance cost especially of cargo vehicles (Gawande \& Kaware, 2013). These maintenances cost and break down of transport vehicle disrupts supply and ultimately increase the price level.

However the overall long run impact of the three petroleum products on CPI appears to be very poor as the adjusted coefficient of determination indicates only 8 percent of variance in CPI is explained by these variables. This apparent poor fit calls for controlling of other extemporaneous variables that could have somehow impacted the CPI. In this regards, since inflation is considered to be always and everywhere a monetary phenomenon, it is intuitive to control monetary impact in the model. Further, as Nepalese currency is pegged to Indian currency and Nepal shares open border with India, co-movement has been observed between inflation of two countries (Ginting, 2007). Therefore, controlling the effect of inflation of India is again intuitive. Following section reevaluates the model by controlling for the possible monetary impact and impact of India's inflation.

\section{b. With Control Variables}

Table 9 details the long run proxied by M2/GDP and price level of India proxied by Wholesale Price of India.

Table 9: NARDL Asymmetry Statistics with Control Variable

\begin{tabular}{|c|c|c|c|c|c|}
\hline \multirow[t]{2}{*}{ Variables (K) } & & \multicolumn{2}{|c|}{ Long Run Effect of K on CPI } & \multicolumn{2}{|c|}{ Asymmetry } \\
\hline & & Effect $(+)$ & Effect(-) & LongRun & Short Run \\
\hline \multirow[t]{2}{*}{ Petrol } & Coeff & 0.003 & -0.098 & \multirow{2}{*}{1.353} & \multirow[t]{2}{*}{0.6348} \\
\hline & F-stat & .004352 & 1.803 & & \\
\hline \multirow[t]{2}{*}{ Diesel } & Coeff & -0.048 & 0.431 & \multirow[t]{2}{*}{$5.278 * * *$} & \multirow[t]{2}{*}{1.277} \\
\hline & F-stat & 0.1215 & $8.09 * * *$ & & \\
\hline \multirow[t]{2}{*}{ Kerosene } & Coeff & -0.008 & -0.114 & \multirow[t]{2}{*}{1.769} & \multirow[t]{2}{*}{0.6342} \\
\hline & F-stat & .004287 & 1.363 & & \\
\hline \multirow[t]{2}{*}{ M2 to GDP } & Coeff & \multicolumn{4}{|l|}{0.0312628} \\
\hline & F-stat & \multicolumn{4}{|l|}{$2.04 * *$} \\
\hline \multirow[t]{2}{*}{ WPI of India } & Coeff & \multicolumn{4}{|c|}{0.4294646} \\
\hline & F-stat & \multicolumn{4}{|c|}{$0.047911 * * *$} \\
\hline \multirow[t]{2}{*}{ Cons } & Coeff & \multicolumn{4}{|c|}{-0.87067} \\
\hline & F-stat & \multicolumn{4}{|c|}{0.5731782} \\
\hline \multicolumn{2}{|c|}{$\begin{array}{l}\text { Bound Test of } \\
\text { nonlinearity }\end{array}$} & \multicolumn{4}{|c|}{$\begin{array}{l}\text { t_BDM }=-10.7626 \quad \text { F_PSS }=17.9240 * * * \\
\text { [above } 99 \text { percent } L B=3.07 \text { and } 99 \text { percent } U B=4.44 \text { as per } P E S A R A N(2001) \text { ] }\end{array}$} \\
\hline \multicolumn{6}{|c|}{ Adj. R square: 0.2636} \\
\hline
\end{tabular}


The NARDL test after introduction of control variable shows an entirely different picture than the one obtained without control in earlier section. First, the result shows that the value of adjusted R2 has improved to 0.2636. However, the analysis has found negligible impact of petrol on CPI in the long run. Further, there was no significant asymmetry in CPI due to change in petrol price. This can be probably explained as petrol is only demanded by high income group whose purchasing power doesn't change with rise or fall in its price. Nevertheless, petrol price rise has negligible but positive impact on CPI with 0.003 unit rise and fall in petrol price is followed by 0.098 unit fall in CPI. This shows that petrol price and CPI have same directional changes. On the other hand, kerosene shows no significant asymmetry in long run. In long run though insignificant, the rise in kerosene by a unit is accompanied by fall in CPI by 0.008 . This could be because as kerosene is generally used by low income group and people might have substituted it for fire woods. The insignificance of kerosene in CPI shows that its impact has fallen in long run as probably consumer has switched to cooking gas. Meanwhile the CPI is found to be most impacted by the diesel with significant asymmetry in its rise and fall in long run. First, rise in diesel though insignificant, is followed by -0.048 unit fall in CPI. This appears to be very counterintuitive as diesel is mainly used by heavy vehicle used for supplying goods and ferrying people. And its increased price should have increased impact in long run. This anomaly could probably be explained as diesel is generally mixed with kerosene and hence rise in diesel might have made users resort to cheaper fuel like kerosene (Yadav et al., 2005). This claim is supported by Kojima (2009) that found when kerosene and diesel price were equalized in Nepal there was 60 percent drop in kerosene and 40 percent increase in diesel consumption. Similarly, fall in diesel price by one unit has significant positive impact on CPI by 0.431 units. This apparent anomaly can be explained intuitively as diesel is the main fuel used by industries for production. Further, during the load shedding period diesel was used mainly for generator. Decrease in diesel price seems to have spurred the industry production which eventually increases the growth thus increasing general price level (Selden, 1959). This assertion is consistent with the literature as according to Parikh and Khedkar (2013) decline in diesel price creates better economic environment for industry. Further, in a study of 18 Eurozone countries, Bayar and Kilic (2014) has shown that with falling fuel price industrial output rises. With rise in industrial output the economic growth ensues that leads to rise in inflation as entailed by Phillip Curve (Mankiw, 1990). Another possible explanation of this could be attributed to fact that as per NRB, transportation that is mainly affected by oil price comprises only 5.34 percent in CPI weight. This finding is extremely interesting as it indicates how attempting to reduce cost push inflation can spillover to demand pull. The long run cointegration however appears to be more impacted by the wholesale price of India and money supply as both are found to be significant determinants of CPI. The cumulative effect of rise and fall in CPI in 
long run because of individual oil products is depicted in the figure 8 . The graph shows that fall in petroleum product across all three items have more impact on CPI than its rise.
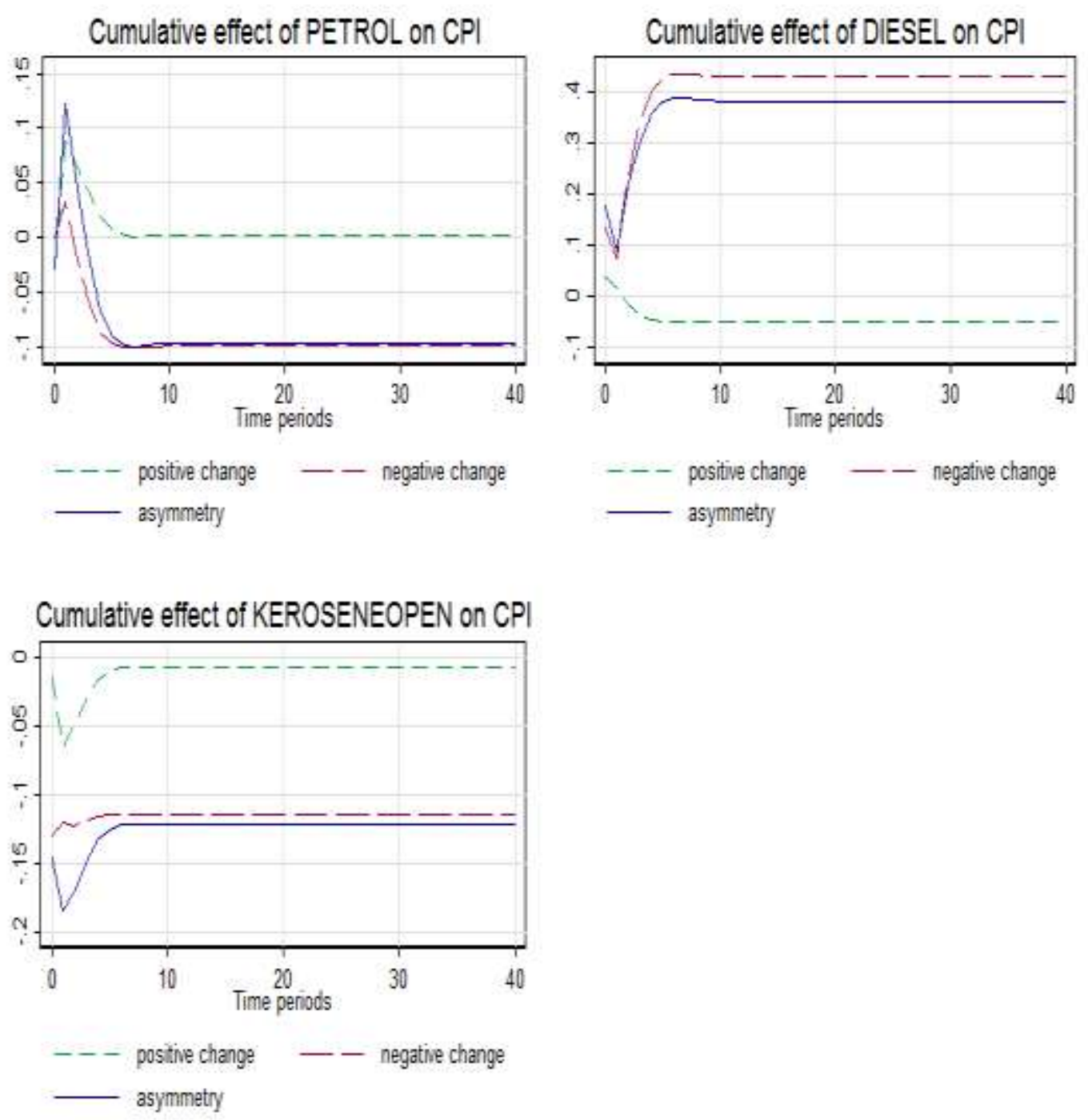

Figure 8: Long Run cumulative impact on CPI by Petrol, Diesel and Kerosene

Meanwhile short run analysis using NARDL is tabulated in table 10. 
Table 10: Short Run NARDL Dynamics

\begin{tabular}{|c|c|c|}
\hline$\Delta$ CPI & Coeff & p-value \\
\hline Cons & -.8706784 & 0.130 \\
\hline CPI(-1) & -.4405832 & o \\
\hline $\operatorname{Petrol}^{+}(-1)$ & .0012158 & 0.947 \\
\hline Petrol- $^{-}(-1)$ & .0433095 & 0.188 \\
\hline $\operatorname{Disel}^{+}(-1)$ & -.0211023 & 0.727 \\
\hline $\operatorname{Disel}^{-}(-1)$ & -.1898633 & 0.006 \\
\hline $\operatorname{Kerosene}^{+}(-1)$ & -.0034793 & 0.948 \\
\hline Kerosene $(-1)$ & .0504165 & 0.241 \\
\hline$\Delta \mathrm{CPI}(-1)$ & .14353 & 0.004 \\
\hline$\Delta \mathrm{CPI}(-2)$ & .1071631 & 0.227 \\
\hline$\Delta$ Petrol $^{+}$ & -.0283891 & 0.538 \\
\hline$\Delta$ Petrol $^{+}(-1)$ & .1071631 & 0.022 \\
\hline$\Delta$ Petrol $^{-}$ & -.0002473 & 0.998 \\
\hline$\Delta$ Petrol $^{-}(-1)$ & -.076688 & 0.535 \\
\hline$\Delta$ Disel $^{+}$ & .0411442 & 0.072 \\
\hline$\Delta \operatorname{Disel}^{+}(-1)$ & .0079936 & 0.949 \\
\hline$\Delta$ Disel $^{-}$ & -.1362581 & 0.549 \\
\hline$\Delta \operatorname{Disel}^{-}(-1)$ & .2105717 & 0.334 \\
\hline$\Delta$ Kerosene $^{+}$ & -.0148427 & 0.884 \\
\hline$\Delta$ Kerosene $^{+}(-1)$ & -.0517161 & 0.639 \\
\hline$\Delta$ Kerosene $^{-}$ & .1307077 & 0.383 \\
\hline$\Delta$ Kerosene $^{-}(-1)$ & -.0227118 & 0.866 \\
\hline WPI India & .4294646 & 0.000 \\
\hline $\mathrm{M} 2$ to GDP & .0312628 & 0.043 \\
\hline
\end{tabular}

The standard Error Correction Model (ECM) shows that a clear short run asymmetry is lacking. However in short run, it is found that unit change in lagged difference of petrol price significantly deviates the CPI by 0.1 units from its long run equilibrium. This suggests that a change in size of price of petrol in previous period increases the CPI. Meanwhile in case of diesel, the fall in price is followed by 0.19 unit fall in CPI bringing the CPI towards convergence. While similar to petrol the unit rise price differential of Diesel deviates the CPI by 0.04 unit from its equilibrium

Thus the findings shows that in short run, it is not the increase in price but the actual size of increase for both diesel and petrol that impacts CPI. This finding has a big policy implication suggesting that modest price rise in petrol and diesel is better than the abrupt hike which may cause disequilibrium in CPI.

\section{CONCLUSION AND RECOMMENDATION}

This paper has examined the impact of oil price pass through into the inflation of Nepal. Though there has been several studies in oil price pass through into inflation across the globe, Nepal presents a unique case for research as it is landlocked and is entirely dependent on India for fuel. Further, the distribution of 
petroleum within the country is done solely by Nepal Oil Corporation. Since inflation has been one of the major factors creating economic hardships especially for fixed income earning groups, NRB needs to formulate monetary policy with an aim to contain it. In view of the fact that monetary policy instruments can address the demand side of inflation, it is important to determine the empirical relationship between inflation and change in oil price

This study shows considerable long run impact of all three petroleum products on the CPI. However, the impact remains consistent only with Diesel after controlling for the monetary component and apparent effect of India's inflation. Meanwhile petrol and kerosene do not appear to exhibit such asymmetry.

Further, study does not find any significant asymmetry in oil price pass through in short run. But the short run increase in CPI can be attributed to size of increase in prices of diesel and petrol rather than the price itself. Since this study employs nonlinear asymmetric model as per the suggestion of Lee et al. (1995) and Hamilton (1996); it can provide guideline for similar future studies as well. Especially since many economic variables such as price, wage are sticky this methodological approach can be employed for their investigation.

The main finding of this study however is the apparent fall in diesel price in long run followed by increase in CPI by 0.44 which can be attributed to increased industrial demand as explained by Bayar and Kilic (2014). This could be explained by fact that the decrease in oil price generates income effect influencing industries to channel their surplus into buying additional raw materials or hiring new labors. Since supply of raw materials and labors do not depend upon oil price, they have apparent constant supply. This increased demand of both raw material and labor eventually could have increases the CPI through demand pull channel. This explanation is aligned with Lemieux (2015), which by applying production possibility frontier curve has shown that in US after the price of crude oil dropped with discovery of fracking, the demand for other goods and service has increased. Thus spawning a long chain effect of change in oil price in consumption, production and eventually into inflation. Another study on US data by Baumeister and Kilian (2016) has shown that decline in price of gasoline has produced 0.7 percentage of real GDP growth by raising private real consumption.

Hence, findings of this study particularly the difference in short run and long run effect of diesel price in CPI opens door for future research on how fall in diesel price apparently has spillover effects into industry and translating it to demand pull inflation. Besides, this study also indicates that the inflation cannot be explained only by oil price alone as suggested by Mankiw (2007); as we have seen significant effect of M2 to GDP and Wholesale Price of India. 
Finally, further studies are recommended to see the interplay of other macroeconomic and monetary indicators along with oil price in influencing the CPI of Nepal. This study, however, shows that since oil price in Nepal is not determined by market mechanism, so pricing authorities should be cautious about the size of price change especially in case of petrol and diesel. Further, this research provides a policy prescription for government to make pricing of diesel more scientific as it has a long run impact on CPI through both industrial demand and through supply chain mechanism.

\section{REFERENCES}

Adam, P., Rianse, U., Cahyono, E., and M. Rahim. 2015. "Modeling of the dynamics relationship between world crude oil prices and the stock market in Indonesia." International Journal of Energy Economics and Policy, 5(2).

Adeniyi, O., Oyinlola, A., and O. Omisakin. 2011. "Oil price shocks and economic growth in Nigeria: are thresholds important?" OPEC Energy Review, 35(4), 308-333.

Ahmed, H. J. A., and I. M. Wadud. 2011. "Role of oil price shocks on macroeconomic activities: An SVAR approach to the Malaysian economy and monetary responses." Energy policy, 39(12), 8062-8069.

Akcelik, F., and F. Öğünç. 2016. "Pass-through of crude oil prices at different stages in Turkey." Central Bank Review, 16(1), 41-51.

Anderson, R. G., Hoffman, D. L., and R. H. Rasche. 2002. "A vector error-correction forecasting model of the US economy." Journal of Macroeconomics, 24(4), 569-598.

Atil, A., Lahiani, A., and D. K. Nguyen. 2014. "Asymmetric and nonlinear pass-through of crude oil prices to gasoline and natural gas prices." Energy Policy, 65, 567-573.

Barro, R. J. 2007. "Milton Friedman: Perspectives, particularly on monetary policy." Cato Journal, 27, 127.

Baumeister, C., and L. Kilian. 2016. "Lower oil prices and the US economy: Is this time different?" Brookings Papers on Economic Activity, 2016(2), 287-357.

Bayar, Y., and C. Kilic. 2014. "Effects of oil and natural gas prices on industrial production in the Eurozone member countries." International Journal of Energy Economics and Policy, 4(2), 238-247.

Bernanke, B. S., Gertler, M., Watson, M., Sims, C. A., and B. M. Friedman. 1997. "Systematic monetary policy and the effects of oil price shocks." Brookings Papers on Economic Activity, 28(1), 91-157.

Bhattarai, K. D. 2017. "Nepal, India sign new oil supply agreement." The Kathmandu Post. 
Bhattarai, R. C., and N. K. Joshi. 2009. "Dynamic Relationship among the Stock Market and the Macroeconomic Factors: Evidence from Nepal." South Asia Economic Journal, 10(2), 451-469.

Bhusal, T. P., and S. Silpakar. 2011. "Growth and inflation: Estimation of threshold point for Nepal." Economic Journal of Development Issues, 131-138.

Blanchard, O., and J. Gali. 2007. "The macroeconomic effects of oil price shocks: Why are the 2000s so different from the 1970s?" Working paper 07-21. Cambridge, MA: Massachusetts Institute of Technology.

Bohi, D. R. 1990. Energy price shocks and macroeconomic performance (No. JHUP0261/XAB).Washington, DC: Resources for the Future.

Bohi, D. R. 1991. "On the macroeconomic effects of energy price shocks." Resources and Energy, 13(2), 145-162.

Bruno, M., and J. D. Sachs. 1985. Economics of worldwide stagflation. Oxford: NBER Books.

Castro, C., Jiménez-Rodríguez, R., Poncela, P., and E. Senra. 2017. "A new look at oil price pass-through into inflation: Evidence from disaggregated European data." Economia Politica, 34(1), 55-82.

Chen, S. S. 2009. "Oil price pass-through into inflation." Energy Economics, 31(1), 126133.

Dahal, P. 2014. "The impact of remittances on economic growth in Nepal: An analysis of a significant basis of development." Asia Pacific Journal of Public Administration, 36(4), 261-282.

DeGregorio, J., Landerretche, O., Neilson, C., Broda, C., and R. Rigobon. 2007. "Another pass-through bites the dust? Oil prices and inflation [with comments]." Economia, 7(2), 155-208.

Dickey, D. A., and W. A. Fuller. 1979. "Distribution of the estimators for autoregressive time series with a unit root." Journal of the American Statistical Association, 74(366), 427-431.

Durotoluwa, O. 2019. High cost of gas and kerosene is driving the use of biomass. Retrieved from https://greenergie.com.ng/2019/03/20/high-cost-of-gas-andkerosene-is-driving-the-use-of-biomass/

Friedman, M. 1963. Inflation: causes and consequences. Asia Publishing House.

Ghimire, B., Gautam, R., Karki, D., and S. Sharma. 2015. "Banks, non-bank companies and stock exchange: do we know the relationship?" Economics and Business Review, 1(4), 25-45.

Granger, C. W. 1969. "Investigating causal relations by econometric models and crossspectral methods." Econometrica: Journal of the Econometric Society, 424-438.

Gawande, A. P., and J. P. Kaware. 2013. "Fuel adulteration consequences in India: a review." Sci Revs Chem Commun, 3(3), 161-171. 
Ginting, E. 2007. Is inflation in India an attractor of inflation in Nepal? (No. 7-269). International Monetary Fund.

Hamburger, M. J., and B. Zwick. 1981. "Deficits, money and inflation." Journal of Monetary Economics, 7(1), 141-150.

Hamilton, J. D. 1996. Analysis of the transmission of oil price shocks through the Macroeconomy. San Diego, mimeo: University of California.

Hamilton, J. D., and A. M. Herrera. 2004. "Oil shocks and aggregate macroeconomic behavior: The role of monetary policy: A comment." Journal of Money, Credit, and Banking, 36(2), 265-286.

Hendry, D. F., and K. Juselius. 2000. "Explaining cointegration analysis: Part 1." The Energy Journal, 1-42.

Hooker, M. A. 2002. "Are oil shocks inflationary?: Asymmetric and nonlinear specifications versus changes in regime." Journal of Money, Credit, and Banking, 34(2), 540-561.

IMF. 2011. IMF country report no. 11/319. Washington, DC: Author.

Iwayemi, A., and B. Fowowe. 2011. "Impact of oil price shocks on selected macroeconomic variables in Nigeria." Energy Policy, 39(2), 603-612.

Johansen, S. 1988. "Statistical analysis of co integration vectors." Journal of Economic Dynamics and Control, 12(2-3), 231-254.

Jongwanich, J., and D. Park. 2011. "Inflation in developing Asia: Pass-through from global food and oil price shocks." Asian-Pacific Economic Literature, 25(1), 79-92.

Ju, K., Zhou, D., Zhou, P., and J. Wu. 2014. "Macroeconomic effects of oil price shocks in China: An empirical study based on Hilbert-Huang transform and event study." Applied Energy, 136, 1053-1066.

Karimili, T., Jafarova, N., Aliyeva, H., and S. Huseynov. 2016. Oil price pass-through into inflation: The evidence from oil exporting countries (No. 01-2016). Graduate Institute of International and Development Studies Working Paper.

Kiptui, M. 2009. "Oil price pass-through into inflation in Kenya." In African Econometric Society (AES) Conference Proceedings.

Koirala, T. P. 2008. "Inflation Expectations in Nepal." Economic Review, Occasional Paper, 20.

Kojima, M. 2009. "Government response to oil price volatility: experience of 49 developing countries." Washington, D.C.: World Bank.

Lee, K., Ni, S., and R. A. Ratti. 1995. "Oil shocks and the macro economy: The role of price variability." The Energy Journal, 39-56.

Lemieux, P. 2015. Cheaper oil will not hurt the economy. Retrieved from https://object.cato.org/sites/cato.org/files/serials/files/regulation/2015/3/regulationv38n1-1.pdf 
Levine, R., and S. Zervos. 1998. "Stock markets, banks, and economic growth." American Economic Review, 537-558.

Lown, C. S., and R. W. Rich. 1997. Is there an inflation puzzle? (No. 9723). New York: Federal Reserve Bank of New York.

Lütkepohl, H. 2005. New introduction to multiple time series analysis. London: Springer Science and Business Media.

Mankiw, N. G. 1990. A quick refresher course in macroeconomics (No. w3256). National Bureau of Economic Research.

Mankiw, G. 2007. Where have all the oil shocks gone? Retrieved from http:// gregmankiw.blogspot.com/2007/10/where-have-all-oil-shocks-gone.html

Mathema, S. R. 1998. "Determinants of Inflation with special reference to wages in Nepal." NRB Economic Review, 10, 1-18.

MacKinnon, J. G., Haug, A. A., and L. Michelis. 1999. "Numerical distribution functions of likelihood ratio tests for cointegration." Journal of Applied Econometrics, 563577.

Mork, K. A. 1989. "Oil and the macro economy when prices go up and down: An extension of Hamilton's results." Journal of Political Economy, 97(3), 740-744.

National Planning Commission. 2018. Nepal's Multidimensional Poverty Index:Analysis towards Action. Kathmandu.

Nielsen, B. 2006. Order determination in general vector autoregressions. Institute of Mathematical Statistics.

NRB. 2011. Comparative analysis of inflation in Nepal and India., Nepal Rastra Bank, Baluwatar, Kathmandu

NRB. 2017. "Optimal Inflation Rate for Nepal." Economic Review, Vol 29, Nepal Rastra Bank, Baluwatar, Kathmandu, Nepal

Paudyal, S. B. 2014. "Determinants of Inflation in Nepal: An Empirical Assessment." NRB Economic Review, 26(2), 61-82.

Osmani, S. R., and B. B. Bajracharya. 2008. Nepal. Handbook on the South Asian Economies, 157.

Pearson, K. 1901. "On lines and planes of closest fit to systems of points in space." The London, Edinburgh, and Dublin Philosophical Magazine and Journal of Science, 2(11), 559-572.

Pesaran, M. H., Shin, Y., and R. J. Smith. 2001. "Bounds testing approaches to the analysis of level relationships." Journal of Applied Econometrics, 16(3), 289-326.

Prasai, L. P. 2014. "Foreign trade pattern of Nepal: Gravity model approach." NRB Economic Review, 26(1), 24-43.

Parikh, J., and G. Khedkar. 2013. "The Impacts of Diesel Price Increases on India's Trucking Industry." International Institute for Sustainable Development. 
Park, J. Y., and P. C. Phillips. 1988. "Statistical inference in regressions with integrated processes: Part 1." Econometric Theory, 4(3), 468-497.

Rao, N. D. 2012. "Kerosene subsidies in India: When energy policy fails as social policy." Energy for Sustainable Development, 16(1), 35-43.

Roeger, W. 2005. "International oil price changes: impact of oil prices on growth and inflation in the EU/OECD." International Economics and Economic Policy, 2(1), 1532 .

Sapkota, S. 2015. "Trade Study Series: A Look at Petroleum and Fertilizer Supply in Nepal." Samriddhi, The Prosperity Foundation.

Sek, S. K., Teo, X. Q., and Y. N. Wong. 2015. "A comparative study on the effects of oil price changes on inflation." Procedia Economics and Finance, 26, 630-636.

Selden, R. T. 1959. "Cost-push versus demand-pull inflation, 1955-57." Journal of Political Economy, 67(1), 1-20.

Shin, Y., Yu, B., and M. "Greenwood-Nimmo. 2014. Modeling asymmetric cointegration and dynamic multipliers in a nonlinear ARDL framework." In Festschrift in Honor of Peter Schmidt (pp. 281-314).Springer, New York, NY.

Shrestha, M. B., and S. K. Chaudhary. 2012. "The impact of food inflation on poverty in Nepal." NRB Economic Review, 24(2), 1-14.

Stock, J. H., and M. W. Watson. 1988. "Testing for common trends. Journal of the American statistical Association, 83(404), 1097-1107.

Suits, D. B., Mason, A., and L. Chan. 1978. "Spline functions fitted by standard regression methods." The Review of Economics and Statistics, 132-139.

Tang, W., Wu, L., and Z. Zhang. 2010. "Oil price shocks and their short-and long-term effects on the Chinese economy." Energy Economics, 32, S3-S14.

Toda, H. Y., and T. Yamamoto. 1995. "Statistical inference in vector auto regressions with possibly integrated processes." Journal of econometrics, 66(1-2), 225-250.

Yadav, S. R., Murthy, V. K., Mishra, D., and B. Baral. 2005. "Estimation of petrol and diesel adulteration with kerosene and assessment of usefulness of selected automobile fuel quality test parameters." International Journal of Environmental Science and Technology, 1(4), 253-255. 